\title{
Natural factors to consider when using acetylcholinesterase activity as neurotoxicity biomarker in Young-Of-Year striped bass (Morone saxatilis)
}

\author{
Eric D. H. Durieux • Thomas B. Farver • \\ Patrick S. Fitzgerald • Kai J. Eder • David J. Ostrach
}

Received: 21 September 2009/Accepted: 14 June 2010/Published online: 27 June 2010

(C) The Author(s) 2010. This article is published with open access at Springerlink.com

\begin{abstract}
Acetylcholinesterase (AChE) activity is one of the most common biomarkers of neurotoxicity used in aquatic organisms. However, compared to its extensive use as biomarker, the effects of natural factors on AChE activity remain unclear especially in estuarine fishes. The aim of this study was to evaluate the effects of natural factors on AChE activity of striped bass (Morone saxatilis) juveniles. Brain AChE activity was measured in YOY (Young-Of-Year) individuals collected monthly from August 2007 to January 2008 at 12 different sites in the San Francisco Estuary system. The spatio-temporal variability of AChE was analyzed relative to water temperature and salinity as well as fish size. AChE activity was highly positively correlated
\end{abstract}

E. D. H. Durieux · P. S. Fitzgerald · K. J. Eder ·

D. J. Ostrach

Pathobiology, Conservation \& Population Biology Laboratory, John Muir Institute of the Environment, Center for Watershed Sciences, University of California, Davis, One Shields Avenue, Davis, CA 95616, USA

Present Address:

E. D. H. Durieux $(\square)$

Centre de Recherche Halieutique Méditerranéenne et Tropicale, IFREMER, Laboratoire Ressources

Halieutiques, Avenue Jean Monnet, BP 171, 34203 Sète cedex, France

e-mail: edh.durieux@gmail.com

\section{T. B. Farver}

Population Health and Reproduction Department, School of Veterinary Medicine, University of California, Davis, One Shields Avenue, Davis, CA 95616, USA with water temperature and to a lesser extent negatively with fish size while no relationship was detected with salinity. Taking into account these natural factors when using AChE as a biomarker will help to determine and understand the effects of neurotoxic contaminants on fish in estuarine systems.

Keywords Fish · Biomarker .

Acetylcholinesterase · Brain - Temperature ·

Salinity $\cdot$ Size

\section{Introduction}

The aquatic environment faces significant chemical contamination from industry, agriculture, urban runoff, and other sources affecting all levels of biological organization from the individual to the entire ecosystem (Schwarzenbach et al. 2006). Biomarkers are "early-warning" signals reflecting the adverse biological responses toward anthropogenic environmental contaminants that are commonly employed in environmental quality and/or risk assessment (van der Oost et al. 2003). Biomarkers are measured within a target organism and can be subdivided into three different categories: (1) biomarkers of exposure (i.e. measurement of exogenous substance indicating xenobiotic contamination); (2) biomarkers of effects (i.e. measurement of biochemical, physiological or other alterations); and (3) biomarkers of susceptibility (i.e. indicating inherent or acquired ability to respond 
to the challenge of exposure. Biomarkers are extensively employed in both laboratory studies in order to define dose-response relationship of target organisms toward specific contaminants and in the field in biomonitoring program in order to assess the response of wild organisms toward the mixture of contaminants present in the environment.

Among the numerous biomarkers available, the measurement of acetylcholinesterase (AChE) activity is one of the most commonly used biomarkers of neurotoxicity. Throughout the entire animal kingdom, $\mathrm{AChE}$ is a key enzyme of the nervous system, its main role is to remove the neurotransmitter acetylcholine within the synapse through hydrolysis. AChE is the target of organophosphates (OPs) and carbamates compounds, which are the most currently in use insecticides worldwide for both domestic and agricultural purposes. The mechanism of toxicity of these insecticides is the inhibition of the enzyme AChE through irreversible or reversible binding of OPs and carbamates, respectively, resulting in the accumulation of acetylcholine at the synapses, and thus disruption of the nervous system function, which leads ultimately to behavioral impairment and even death. Enzyme inhibition in contaminated organisms often times persists for an extended period of time, while OPs and carbamates insecticide detection in the environment may prove unsuccessful due to their rapid degradation (Fulton and Key 2001). In addition, several other studies have shown AChE inhibition caused by other compounds such as polycyclic aromatic hydrocarbons (Payne et al. 1996), heavy metals (Bocquené et al. 1995) and herbicides (Moraes et al. 2007), so that AChE activity appears as a relevant means of investigating biological effects of complex mixture of many neurotoxic contaminants on aquatic environments (Lionetto et al. 2005). Fish behavior (i.e. balance, swimming or feeding) is clearly related to $\mathrm{AChE}$ activity in brain and muscle (Scholz et al. 2000; Scott and Sloman 2004; Sandahl et al. 2005); thus, the detection of this enzyme inhibition is also recognized as an early sign of behavioral impairments, which may, in turn, reduce survival leading to population level effects (Baldwin et al. 2009).

Compared to the extensive use of AChE as a biomarker in fish, studies on the natural variation of the activity of this enzyme are relatively scarce. The effect of temperature on AChE activity in the central nervous system of fishes has been documented, however, giving inconsistent results (Lionetto et al. 2005; Oliveira et al. 2005). For instance, Hogan (1970), who performed a field experiment on bluegill Lepomis Macrochirus, showed a strong seasonal variation of brain AChE activity positively linked to water temperature. In contrast, in a more recent laboratory study on the latter species, Beauvais et al. (2002) found no difference in brain AChE activity of fish acclimated to different water temperatures. Moreover, AChE activity is extremely variable between species (Bocquené et al. 1990), so that species differences in response to natural factors need to be considered as well. Natural factors have to be taken into account, since environmental variables may have a direct or indirect effect on AChE activity. It appears necessary to separate the variations due to pollution from the natural variability in order to correctly use this biomarker especially in the case of biomonitoring programs (Pfeifer et al. 2005).

The San Francisco Estuary is well known for the diverse anthropogenic pressures that have highly altered the functioning of this ecosystem (Bennett and Moyle 1996; Thompson et al. 2000; Sommer et al. 2007; Strange 2008). The striped bass (Morone saxatilis) is the most important piscivorous fish of the estuary. It was introduced from the East coast of USA in the late 1880 s, and it supports a valuable recreational fishery. Along with other pelagic fishes, the striped bass population has suffered significant declines in the past decades in the San Francisco Estuary (Bennett and Moyle 1996; Feyrer et al. 2007). Among the multiple stressors affecting the aquatic fauna in this dynamic and complex ecosystem, contaminants are considered to play a significant role (Stevens et al. 1985; Bailey et al. 1994; Bennett et al. 1995; Ostrach et al. 2008). Contaminant inputs are diverse and sources such as agriculture, industry, and urban runoff into the estuary have been documented (Thompson et al. 2000). However, with the exception of the Regional Monitoring Program conducted by the San Francisco Estuary Institute characterizing the contaminants in a small portion of the San Francisco delta (SFEI 2008), there is no data on contaminant levels throughout the majority of the range of juvenile striped bass in this system. The measurement of AChE activity in striped bass appears therefore to be a relevant metric to investigate exposure and effects of neurotoxic contaminants in this valuable sentinel species. 
The aim of this study was to distinguish between natural and contaminant-based changes when using $\mathrm{AChE}$ activity as a neurotoxicity biomarker under field conditions in Young-Of-Year (YOY) juvenile striped bass in the San Francisco Estuary. The YOY life stage was chosen because over 30 years of monitoring data, and various studies suggest that important factors causing the striped bass population decline occur in the early life stages up through the 38-mm YOY index (Bailey et al. 1994; Bennett et al. 1995; Sommer et al. 2007; Ostrach et al. 2008). This YOY index has been used to accurately measure recruitment and population abundance of striped bass for more than 40 years (Kimmerer et al. 2000). Striped bass spawn in the late spring and summer and reach YOY status in early fall (Kimmerer et al. 2000). Brain AChE activity was measured in YOY individuals collected monthly from August 2007 to January 2008 at 12 different sites in the San Francisco Estuary system. The 12 sites chosen are part of the California Department of Fish and Game monitoring survey and encompass the entire range in which the early life stages of striped bass occur in the San Francisco Estuary (Bennett et al. 1995; Sommer et al. 2007). We first analyzed the effects of the natural factors water temperature, salinity and fish size on AChE activity. In a second step, we analyzed difference in AChE activity of striped bass between the different sites while taking into account the effects of the significant natural factors.

\section{Materials and methods}

Fish origin

This study was conducted with the approval of the UC Davis Institutional Animal Care and Use Committee.

Young-Of-Year striped bass were sampled monthly from August 2007 to January 2008 at 12 sites throughout the San Francisco Estuary (Northern California, USA, Table 1; Fig. 1) in collaboration with the California Department of Fish and Game. Water temperature and conductivity were recorded for each site sampled at the time of collection. Onboard, immediately after capture, fork lengths were recorded, and fish were killed by quickly severing the central nervous system posterior to the head. Fish were dissected to extract the brain which was placed into coded vials and snap frozen in liquid nitrogen. At the laboratory, brain samples were transferred to a $-80^{\circ} \mathrm{C}$ Revco freezer until $\mathrm{AChE}$ analysis was performed. Otoliths were also collected, stored in coded vials, and age estimation was performed at the laboratory so that only YOY were selected for this study.

\section{AChE assay}

Acetylcholinesterase activity in the brains of juvenile striped bass was analyzed similar to the method
Fig. 1 Location of the 12 sampling sites for YoungOf-Year juveniles striped bass (Morone saxatilis) in the San Francisco Estuary (Northern California, USA)

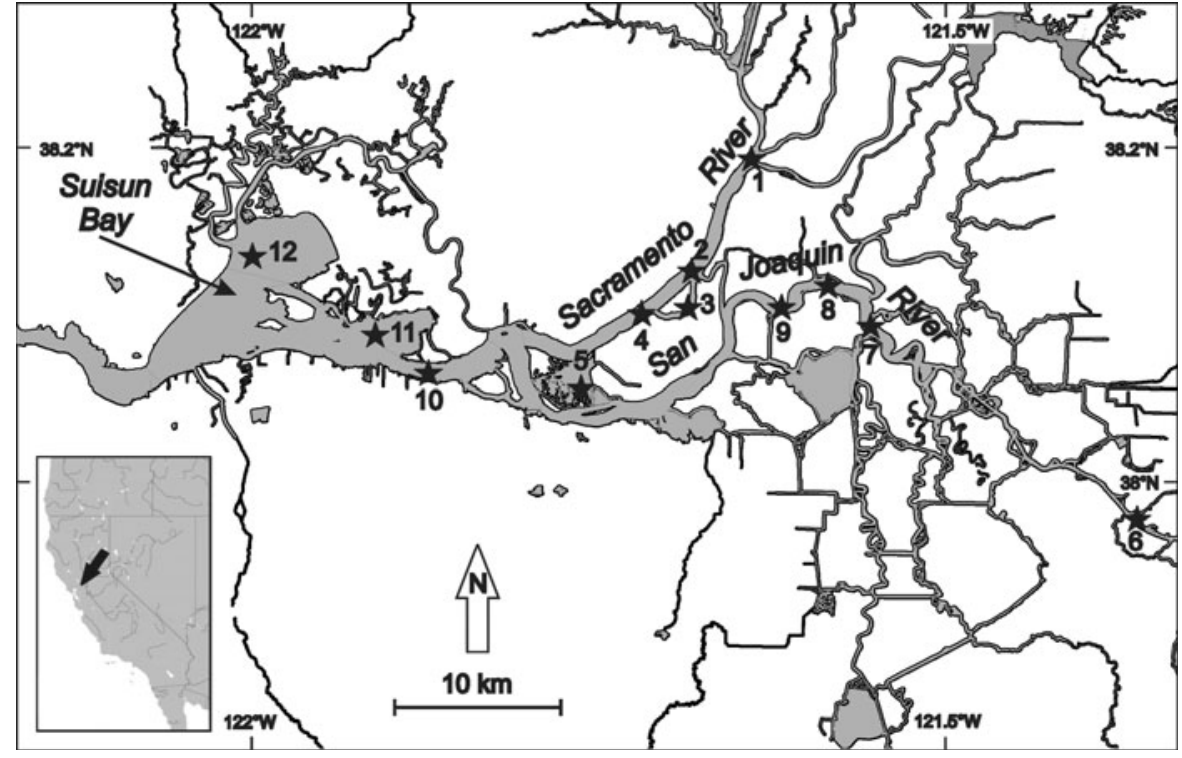


described by Wheelock et al. (2005) for Chinook salmon. Samples were weighed, diluted 1:10 (mg: $\mu \mathrm{l})$ in $0.1 \mathrm{M}$ sodium phosphate buffer $(\mathrm{pH} 8.0)$ with $0.5 \%$ Triton X-100, and homogenized for 1 min using a glass douncer on ice. Homogenates were centrifuged at $4^{\circ} \mathrm{C}$ for $10 \mathrm{~min}$ at $7,000 \mathrm{~g}$ to remove large particulate material. The supernatant fraction was transferred to separate tubes, and the total protein concentration was determined with the Bio-Rad DC Protein Assay (Bio-Rad Laboratories, Hercules, CA) using bovine serum albumin as a standard (Wheelock et al. 2005). The AChE assay was modified and performed using optimized conditions developed in the laboratory for striped bass brain as follows: sodium phosphate buffer $(0.1 \mathrm{M}, \mathrm{pH} 8.0)$ with $0.5 \%$ Triton X-100 (Sigma-Aldrich) was added to the supernatant fraction for a final dilution of 1:250 (mg: $\mu \mathrm{l})$. About $30 \mu \mathrm{l}$ of diluted supernatant was transferred to microplate wells containing $250 \mu \mathrm{l}$ of $0.1 \mathrm{M}$ sodium phosphate buffer $(\mathrm{pH} 8.0), 10 \mu \mathrm{l}$ of 5,5'-dithiobis-2-nitrobenzoic acid (DTNB) (final concentration of $0.32 \mathrm{mM}$ ), and $30 \mu \mathrm{l}$ acetylthiocholine iodide (AtChI) (final concentration of $2 \mathrm{mM}$ ). Samples were run in triplicates, and absorbance at $405 \mathrm{~nm}$ was measured at 2 -min intervals for $10 \mathrm{~min}$ at $25^{\circ} \mathrm{C}$ with an automated microplate reader (SpectraMax Plus 384). Substrate blanks were included on each plate, and all samples were corrected for background hydrolysis. All activities were calculated as nmol $\min ^{-1} \mathrm{~g}^{-1}$ wet weight then normalized to protein content (nmol $\mathrm{min}^{-1} \mathrm{mg} \mathrm{prot}^{-1}$ ).

Data analysis

Acetylcholinesterase data were log transformed to meet normality and homogeneity of variances assumptions.

Relationships between $\mathrm{AChE}$ and natural factors (i.e. temperature, salinity and size) were assessed by backward stepwise multiple regression. To take into account non-linear relationships between response and predictors, polynomial regression was included in the multiple regression analysis (Legendre and Legendre 1998). AChE values were then compared between sites and regions for each sampling month using one-way ANCOVA using as covariates the significant variables (natural factors) previously identified in the regression analysis. Tests were considered significant at $\alpha=5 \%$.

\section{Results}

A clear seasonal change in AChE activity of YOY striped bass was observed over the sampling period with decrease from summer to winter (Fig. 2). Precisely, AChE activity remained around $250 \mathrm{nmol} \mathrm{min}{ }^{-1} \mathrm{mg} \mathrm{prot}^{-1}$ from August to October then dropped progressively to reach approximately $100 \mathrm{nmol} \mathrm{min}{ }^{-1} \mathrm{mg} \operatorname{prot}^{-1}$ in January. Multiple regression analysis revealed significant positive relationship between $\mathrm{AChE}$ and water temperature (Table 2; Fig. 3). This relationship being non-linear, the addition of the polynomial component Temperature $^{2}$ improved substantially the model fit. In order to remove multicolinearity due to the addition of the polynomial component, the Temperature was first grand-mean centered. To a lesser extent, a significant negative relationship between AChE activity and fish size was also found (Table 2; Fig. 4). On the other hand, no relationship was found with salinity, so that it was automatically removed from the stepwise regression analysis. The significant variables identified in the multiple regression analysis (namely Temperature, Temperature ${ }^{2}$ and Length) were then used as covariates in ANCOVAs testing differences in AChE activity between sites (Table 3). ANCOVAs revealed significant difference between sites only in January with lower AChE activity for fish sampled in Suisun Bay (sites 11 and 12) compared to other sites from the Sacramento and San Joaquin Rivers.

\section{Discussion}

When measuring a biomarker in the field as part of a biomonitoring program, variability of the measured biological endpoint is to be expected. However, natural variability has to be distinguished from the variability resulting from contaminant exposure and their effects. Here, we investigated the variability of the neurotoxicity biomarker AChE activity in striped bass YOY juveniles from the San Francisco Estuary that experienced temporal and spatial natural variations in term of both intrinsic (i.e. size/age) and extrinsic (water temperature and salinity) factors. This study highlights the natural factors to account for when using AChE activity as a neurotoxicity biomarker in biomonitoring programs for this species. 
Table 1 Water temperature $\left({ }^{\circ} \mathrm{C}\right)$ and salinity (psu), sample size (n) and mean fork length $( \pm \mathrm{SD})$ (in $\mathrm{mm}$ ) of YoungOf-Year juveniles striped bass (Morone saxatilis) for 12 sites of the San

Francisco Estuary (Northern California, USA) sampled monthly from August 2007 to January 2008. The different regions sampled in the Estuary (SR Sacramento River, SJR San Joaquin River, $S B$ Suisun Bay) are also represented

\begin{tabular}{|c|c|c|c|c|c|c|}
\hline Month & Region & Site & Temperature & Salinity & $n$ & Length $\pm \mathrm{SD}$ \\
\hline \multirow[t]{4}{*}{ A } & \multirow[t]{2}{*}{ SR } & 1 & 23.4 & 0.0 & 1 & 68.0 \\
\hline & & 2 & 21.8 & 0.0 & 5 & $76.0 \pm 8.4$ \\
\hline & \multirow[t]{2}{*}{ SJR } & 8 & 22.9 & 0.0 & 5 & $96.0 \pm 8$ \\
\hline & & 9 & 21.7 & 0.0 & 4 & $112.5 \pm 9.0$ \\
\hline \multirow[t]{5}{*}{ S } & \multirow[t]{2}{*}{ SR } & 2 & 18.6 & 0.0 & 7 & $88.4 \pm 11.2$ \\
\hline & & 5 & 18.9 & 0.0 & 1 & 94.0 \\
\hline & \multirow[t]{2}{*}{ SJR } & 6 & 23.7 & 0.0 & 1 & 125.0 \\
\hline & & 9 & 19.6 & 0.0 & 8 & $130.4 \pm 9.5$ \\
\hline & SB & 12 & 18.5 & 10.2 & 15 & $110.9 \pm 8.2$ \\
\hline \multirow[t]{5}{*}{$\mathrm{O}$} & \multirow[t]{2}{*}{ SR } & 2 & 16.1 & 0.0 & 6 & $88.5 \pm 10.5$ \\
\hline & & 4 & 16.2 & 2.8 & 3 & $83.7 \pm 8.5$ \\
\hline & \multirow[t]{2}{*}{ SJR } & 7 & 16.5 & 0.0 & 5 & $114.6 \pm 9.1$ \\
\hline & & 9 & 16.4 & 0.0 & 6 & $115.3 \pm 6.3$ \\
\hline & SB & 10 & 15.9 & 7 & 16 & $101.5 \pm 12.6$ \\
\hline \multirow[t]{7}{*}{$\mathrm{N}$} & \multirow[t]{2}{*}{ SR } & 2 & 14.6 & 0.0 & 1 & 93.0 \\
\hline & & 3 & 12 & 0.0 & 6 & $114.3 \pm 9.3$ \\
\hline & \multirow[t]{2}{*}{ SJR } & 7 & 14.6 & 0.0 & 3 & $123.7 \pm 13.9$ \\
\hline & & 9 & 14.4 & 0.0 & 7 & $120.0 \pm 10.0$ \\
\hline & \multirow[t]{3}{*}{ SB } & 10 & 13.5 & 6.0 & 6 & $108.5 \pm 17.6$ \\
\hline & & 11 & 14.9 & 8.725 & 8 & $111.6 \pm 12.2$ \\
\hline & & 12 & 15.1 & 13.4 & 13 & $96.4 \pm 12.9$ \\
\hline \multirow[t]{5}{*}{$\mathrm{D}$} & SR & 3 & 9.1 & 0.0 & 2 & $112.5 \pm 3.5$ \\
\hline & SJR & 9 & 9.7 & 0.0 & 2 & $100.5 \pm 16.5$ \\
\hline & \multirow[t]{3}{*}{ SB } & 10 & 9.3 & 6.6 & 1 & 113.0 \\
\hline & & 11 & 9.9 & 13.5 & 10 & $108.8 \pm 9.3$ \\
\hline & & 12 & 9.9 & 17.2 & 14 & $129.8 \pm 9.1$ \\
\hline \multirow[t]{4}{*}{$\mathrm{J}$} & SR & 3 & 7.8 & 0.0 & 3 & $106.7 \pm 9.5$ \\
\hline & SJR & 9 & 8.5 & 0.0 & 7 & $125.0 \pm 21.5$ \\
\hline & \multirow[t]{2}{*}{ SB } & 11 & 7.8 & 0.0 & 4 & $122.8 \pm 10.9$ \\
\hline & & 12 & 8.1 & 4.2 & 5 & $105.4 \pm 14.0$ \\
\hline
\end{tabular}

Our study showed a strong positive relationship between water temperature and AChE activity of YOY striped bass. In the literature, the role of temperature on AChE activity in the central nervous system of fishes has been investigated through both laboratory acclimation studies and field studies giving contradictory results between and within each of these approaches. During thermal acclimation, different types of changes in rate functions can occur (Precht 1958): (1) overcompensation, (2) perfect compensation, the acclimated rates being the same at the two temperatures, (3) partial compensation, (4) no compensation, and (5) inverse or paradoxical change, the acclimated rate in cold being lower than the rate on direct transfer from warm to cold. From acclimation studies, it has been reported that brain AChE activity varied inversely with the temperature of acclimation in killifish Fundulus heteroclitus (Baslow and Nigrelli 1964). Conversely, Hazel (1969) reported no change in AChE activity of killifish with respect to temperature and positive change in AChE activity of goldfish with increasing temperature. Baldwin and Hochachka (1970) showed that AChE activity of rainbow trout Oncorhynchus mykiss was the same at the different acclimated temperatures, and they demonstrated that this compensation mechanism was linked to the presence of different isozymes specifically suited to the different acclimation temperatures. More recently, two studies 


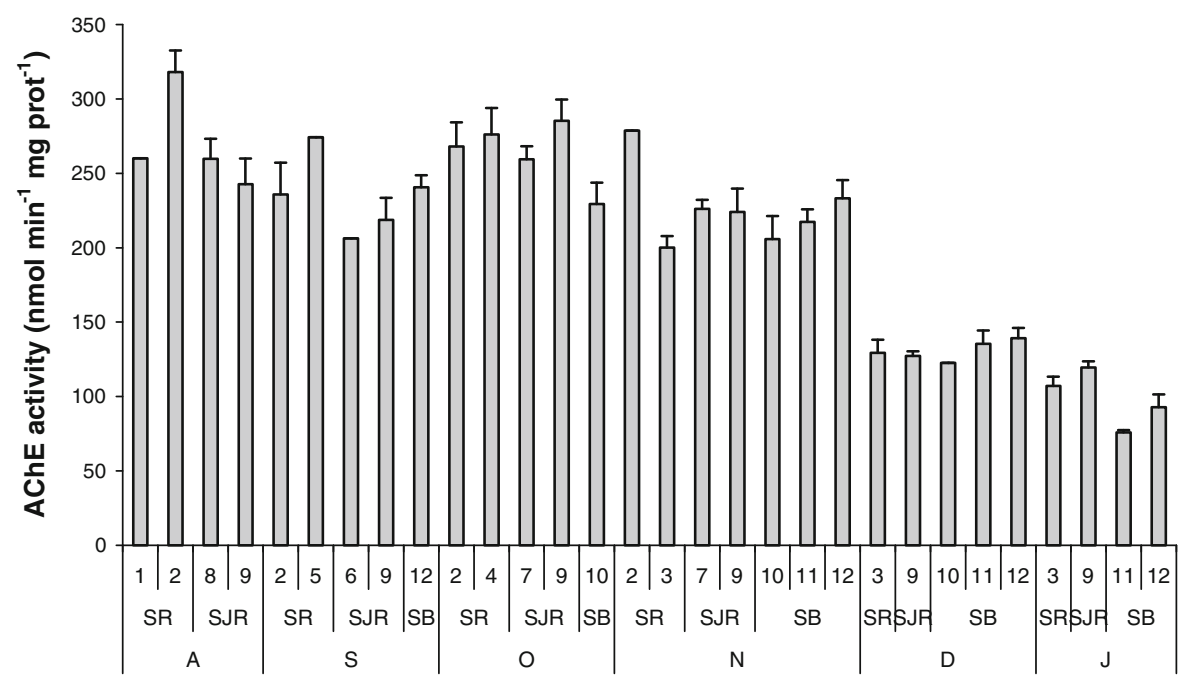

Fig. 2 Monthly mean $( \pm \mathrm{SE})$ AChE activity (nmol min ${ }^{-1}$ $\mathrm{mg} \mathrm{prot}^{-1}$ ) of Young-Of-Year juveniles striped bass (Morone saxatilis) collected from August 2007 to January 2008 in 12 sampling sites from the San Francisco Estuary (Northern

Table 2 Details of the $\log$ AChE activity model obtained from stepwise multiple regression analysis based on water Temperature $\left({ }^{\circ} \mathrm{C}\right)$, Temperature ${ }^{2}$ and fork length $(\mathrm{mm})$ predictive variables for Young-Of-Year striped bass (Morone saxatilis) collected monthly from August 2007 to January 2008 in 12 sampling sites from the San Francisco Estuary (Northern California, USA). Details of the model include: parameter values and standard deviation (SD); Student's t test value for parameter estimation and associated $P$-value $(P)$; Variance Inflation Factor for the variables (VIF); the coefficient of determination $\left(R^{2}\right)$

\begin{tabular}{lrlcll}
\hline Parameter & Value & SD & Student's t & VIF & $P$ \\
\hline Intercept & 2.447 & 0.041 & 59.426 & & $<0.0001$ \\
Temperature & 0.028 & 0.002 & 17.818 & 1.114 & $<0.0001$ \\
Temperature $^{2}$ & -0.003 & 0.000 & -9.591 & 1.001 & $<0.0001$ \\
Length & -0.001 & 0.000 & -2.477 & 1.115 & 0.014 \\
$R^{2}$ & 0.741 & & & & \\
\hline
\end{tabular}

$N B$ no significant relationship was found with salinity, so that it was automatically removed from the stepwise multiple regression analysis

showed no differences in brain AChE activity in walleye Stizostedion vitreum and bluegill Lepomis Macrochirus acclimated to different water temperatures (Beauvais et al. 2002; Phillips et al. 2002). However, the latter authors did not evoke compensation mechanism in the enzymatic activity of AChE relative to water temperature and concluded that water temperature had no effect on AChE activity. In
California, USA). The three different regions sampled in the Estuary ( $S R$ Sacramento River, SJR San Joaquin River, $S B$ Suisun Bay) are represented

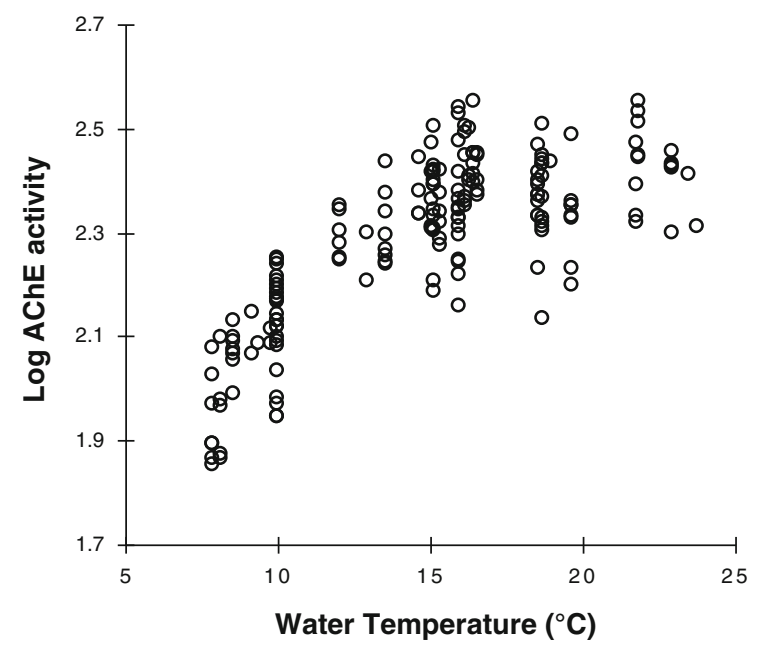

Fig. 3 Relationship between $\log$ AChE activity and water temperature in Young-Of-Year striped bass (Morone saxatilis) collected monthly from August 2007 to January 2008 in the San Francisco Estuary (Northern California, USA)

contrast, Hogan (1970), who performed a field experiment, showed in bluegill a strong seasonal variation of brain AChE activity that was positively linked to water temperature. Other field studies corroborated such results on the influence of water temperature on $\mathrm{AChE}$ activity in several marine fishes (Bocquené et al. 1990; Kopecka and Pempkowiak 2008). However, other authors reported the lack of relationship between 


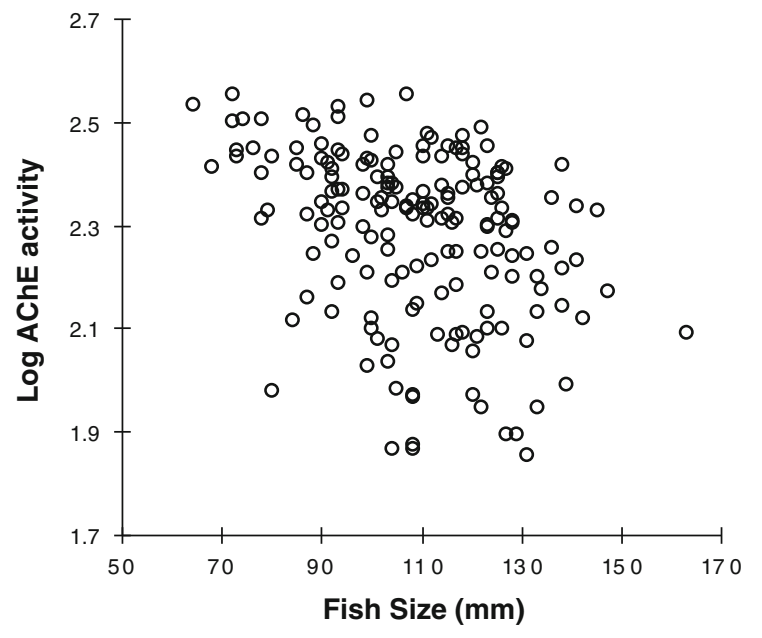

Fig. 4 Relationship between $\log$ AChE activity and fish size (fork length) in Young-Of-Year striped bass (Morone saxatilis) collected monthly from August 2007 to January 2008 in the San Francisco Estuary (Northern California, USA)

Table 3 Results of ANCOVAs testing differences in $\log$ AChE activity between sites for each month using Temperature, Temperature ${ }^{2}$ and fish size as covariates for Young-OfYear striped bass (Morone saxatilis) collected monthly from August 2007 to January 2008 in 12 sampling sites from the San Francisco Estuary (Northern California, USA). With: degrees of freedom $(d f)$; Fisher's $F$ and associated $P$-value $(P)$

\begin{tabular}{llll}
\hline Month & $d f$ & Fisher's $F$ & $P$ \\
\hline A & $4-10$ & 2.466 & 0.113 \\
S & $6-25$ & 1.011 & 0.441 \\
O & $5-30$ & 2.388 & 0.062 \\
N & $8-35$ & 1.146 & 0.358 \\
D & $5-23$ & 0.194 & 0.962 \\
J & $4-14$ & 6.978 & 0.003 \\
\hline
\end{tabular}

AChE activity and water temperature in different marine and freshwater fishes (Chuiko et al. 1997; Kirby et al. 2000; Flammarion et al. 2002). In other field studies performed on different aquatic invertebrate species, a positive relationship between AChE activity and water temperature has been recently demonstrated (Scaps and Borot 2000; Pfeifer et al. 2005; Cailleaud et al. 2007). Based on the adaptive capacities of fish in acclimation conditions, experimental acclimation studies have the potential to overlook any seasonal effect of temperature on AChE activity in fish that occur in natural conditions. Alternatively field studies performed on a too short period of time could also possibly overlook seasonal variation in AChE activity. This study provides new important up-to-date information concerning the effect of temperature as an important natural factor influencing AChE variation in wild fishes in general and in striped bass in particular.

We did not find any effect of salinity on AChE activity in striped bass juveniles. Salinity seems to have an effect on AChE activity in invertebrates such as polychaete, mussel and copepod (Scaps and Borot 2000; Pfeifer et al. 2005; Cailleaud et al. 2007). However, to our knowledge, the effect of salinity on AChE activity has never been reported in fishes. While salinity may not modulate constitutive AChE expression in fish, elevated salinity can increase the metabolism of organophosphate insecticides (Lavado et al. 2009), which could have the potency to enhance AChE inhibition. However, Wang et al. (2001) demonstrated that salinity-induced enhanced toxicity of the carbamate aldicarb was species dependent, observed in Oncorhynchus mykiss but not in hybrid striped bass (Morone saxatilis $\times$ chrysops), which mitigates this assumption in striped bass. Concerning intrinsic factors, AChE activity was negatively related to the size of YOY striped bass. Such negative relationship between AChE activity and fish size has been shown for several fishes in both juveniles and adults (Chuiko et al. 1997; Beauvais et al. 2002; Flammarion et al. 2002; Phillips et al. 2002). Another intrinsic factor that could have been taken into account would have been the sex. In this study, since individuals were all YOY and striped bass do not become sexually mature prior to 4 years of age, the sex gender was not determined. In fact, there is a consistency in the literature that the sex gender has no influence on AChE activity in both juvenile and adult stages of fishes (Hogan 1970; Kirby et al. 2000; Beauvais et al. 2002; Lionetto et al. 2003) such that it can be ignored as a factor in AChE activity.

Taking into account the variation of AChE activity linked to natural factors (i.e. temperature and size as covariates), AChE activity was significantly different between sites of the San Francisco Estuary in January with a lower activity in fish collected in Suisun Bay sites than those collected in sites of the Sacramento and San Joaquin rivers. This single finding of AChE activity reduction (around 25\%), not due to the measured environmental factors (extrinsic and intrinsic), might therefore result from a neurotoxic contamination origin. No contaminants data matching the spatio-temporal sampling design of this study are 
available. The Regional Monitoring Program, conducted annually by the San Francisco Estuary Institute and which focuses essentially on persistent contaminants, has indicated the presence of several compounds at higher levels in Suisun Bay than in the rivers, and among them some potent $\mathrm{AChE}$ inhibitors such as PAHs and heavy metals (SFEI 2008), which might corroborate this finding. However, the dynamics of contaminants is very complex in this system, and many compounds that are discharged into the San Francisco estuary are not being monitored, and very few degradation products are analyzed (Kuivila and Hladik 2008). Thus, instead of linking AChE activity to specific compounds, this result rather highlights the occurrence of a general neurotoxic event in Suisun Bay in the January month. According to other studies evaluating the relationship between AChE activity and toxic effects, such inhibition is in the sublethal range and might not cause direct mortality (Fulton and Key 2001). However, because AChE activity and behavior are tightly linked, this slight decrease in AChE can result in impaired behavior and thus reduced survival.

In conclusion, AChE activity was strongly positively related to water temperature and to a lesser extent negatively to fish size, while no relationship was detected with salinity. Taking into account these natural factors when using $\mathrm{AChE}$ as a biomarker will help to determine and understand the effects of neurotoxic contaminants on fish in estuarine systems.

Acknowledgments Funding for this study was provided by the Interagency Ecological Study Program Pelagic Organism Decline Investigations, Department of Water Resources contract No. 4600004664. Special thanks to CDFG, Randy Baxter and all of the crews involved in sampling assistance; to the POD managers in particular Ted Sommer who supported this project. We are grateful to the anonymous referees for valuable comments and corrections on the manuscript.

Open Access This article is distributed under the terms of the Creative Commons Attribution Noncommercial License which permits any noncommercial use, distribution, and reproduction in any medium, provided the original author(s) and source are credited.

\section{References}

Bailey HC, Alexander C, Digiorgio C, Miller M, Doroshov SI, Hinton DE (1994) The effect of agricultural discharge on striped bass (Morone saxatilis) in California's Sacramento-San Joaquin drainage. Ecotoxicol 3:123-142
Baldwin J, Hochachka PW (1970) Functional significance of isoenzymes in thermal acclimatization. Acetylcholinesterase from trout brain. Biochem J 116:883-887

Baldwin DH, Spromberg JA, Collier TK, Scholz NL (2009) A fish of many scales: extrapolating sublethal pesticide exposures to the productivity of wild salmon populations. Ecol Appl 19:2004-2015

Baslow M, Nigrelli R (1964) The effect of thermal acclimation on brain cholinesterase activity of the killifish, Fundulus heteroclitus. Zoologica 49:41-51

Beauvais SL, Cole KJ, Atchison GJ, Coffey M (2002) Factors affecting brain cholinesterase activity in bluegill (Lepomis Macrochirus). Water Air Soil Pollut 135:249-264

Bennett W, Moyle P (1996) Where have all the fishes gone? Interactive factors producing fish declines in the Sacramento-San Joaquin Estuary. In: Holligaugh J (ed) San Francisco Bay: the ecosystem. Pacific Division of the American Association for the Advancement of Science, San Francisco, pp 479-518

Bennett WA, Ostrach DJ, Hinton DE (1995) Larval striped bass condition in a drought-stricken estuary: evaluating pelagic food-web limitation. Ecol Appl 5:680-692

Bocquené G, Galgani F, Truquet P (1990) Characterization and assay conditions for use of AChE activity from several marine species in pollution monitoring. Mar Environ Res 30:75-89

Bocquené G, Bellanger C, Cadiou Y, Galgani F (1995) Joint action of combinations of pollutants on the acetylcholinesterase activity of several marine species. Ecotoxicol 4:266-279

Cailleaud K, Maillet G, Budzinski H, Souissi S, Forget-Leray J (2007) Effects of salinity and temperature on the expression of enzymatic biomarkers in Eurytemora affinis (Calanoida, Copepoda). Comp Biochem Physiol Part A Mol Integr Physiol 147:841-849

Chuiko GM, Zhelnin Y, Pod'gornaya VA (1997) Seasonal fluctuations in brain acetylcholinesterase activity and soluble protein content in roach (Rutilus rutilus L.): a freshwater fish from northwest Russia. Comp Biochem Physiol Part C Pharmacol Toxicol Endocrinol 117: 251-257

Feyrer F, Nobriga ML, Sommer TR (2007) Multidecadal trends for three declining fish species: habitat patterns and mechanisms in the San Francisco Estuary, California, USA. Can J Fish Aquat Sci 64:723-734

Flammarion P, Noury P, Garric J (2002) The measurement of cholinesterase activities as a biomarker in chub (Leuciscus cephalus): the fish length should not be ignored. Environ Pollut 120:325-330

Fulton MH, Key PB (2001) Acetylcholinesterase inhibition in estuarine fish and invertebrates as an indicator of organophosphorus insecticide exposure and effects. Environ Toxicol Chem 20:37-45

Hazel J (1969) The effect of thermal acclimation upon brain acetylcholinesterase activity of Carassius auratus and Fundulus heteroclitus. Life Sci 8:775-784

Hogan JW (1970) Water temperature as a source of variation in specific activity of brain acetylcholinesterase of bluegills. Bull Environ Contam Toxicol 5:347-353

Kimmerer WJ, Cowan JH, Miller LW, Rose KA (2000) Analysis of an estuarine striped bass (Morone saxatilis) 
population: influence of density-dependent mortality between metamorphosis and recruitment. Can J Fish Aquat Sci 57:478-486

Kirby MF et al (2000) The use of cholinesterase activity in flounder (Platichthys flesus) muscle tissue as a biomarker of neurotoxic contamination in UK estuaries. Mar Poll Bull 40:780-791

Kopecka J, Pempkowiak J (2008) Temporal and spatial variations of selected biomarker activities in flounder (Platichthys flesus) collected in the Baltic proper. Ecotoxicol Environ Saf 70:379-391

Kuivila K, Hladik M (2008) Understanding the occurence and transport of current-use pesticides in the San Francisco Estuary Watershed. San Francisco estuary and watershed science 6. Retrieved from: http://escholarship.org/uc/item/ 06n8b36k

Lavado R, Rimoldi JM, Schlenk D (2009) Mechanisms of fenthion activation in rainbow trout (Oncorhynchus mykiss) acclimated to hypersaline environments. Toxicol Appl Pharmacol 235:143-152

Legendre P, Legendre L (1998) Numerical ecology, 2nd English edn. Elsevier Science BV, Amsterdam

Lionetto MG, Caricato R, Giordano ME, Pascariello MF, Marinosci L, Schettino T (2003) Integrated use of biomarkers (acetylcholinesterase and antioxidant enzymes activities) in Mytilus galloprovincialis and Mullus barbatus in an Italian coastal marine area. Mar Poll Bull 46:324-330

Lionetto M, Caricato R, Giordano M, Schettino T (2005) Acetylcholinesterase as biomarker in environmental biomonitoring. In: Parveen M, Kumar S (eds) Recent trends in the acetylcholinesterase system. IOS Press, Amsterdam, pp 91-102

Moraes BS et al (2007) Effects of four rice herbicides on some metabolic and toxicology parameters of teleost fish (Leporinus obtusidens). Chemosphere 68:1597-1601

Oliveira R, Ciro A, de Assis S, Cristina H (2005) AChE inhibition as a biomarker for pollutants contamination in tropical aquatic ecosystems. In: Parveen M, Kumar S (eds) Recent trends in the acetylcholinesterase system. IOS Press, Amsterdam, pp 103-124

Ostrach DJ, Low-Marchelli JM, Eder KJ, Whiteman SJ, Zinkl JG (2008) Maternal transfer of xenobiotics and effects on larval striped bass in the San Francisco Estuary. Proc Natl Acad Sci USA 105:19354-19359

Payne JF, Mathieu A, Melvin W, Fancey LL (1996) Acetylcholinesterase, an old biomarker with a new future? Field trials in association with two urban rivers and a paper mill in Newfoundland. Mar Poll Bull 32:225-231

Pfeifer S, Schiedek D, Dippner JW (2005) Effect of temperature and salinity on acetylcholinesterase activity, a common pollution biomarker, in Mytilus sp. from the south-western Baltic Sea. J Exp Mar Biol Ecol 320:93-103

Phillips TA, Summerfelt RC, Atchison GJ (2002) Environmental, biological, and methodological factors affecting cholinesterase activity in walleye (Stizostedion vitreum). Arch Environ Contam Toxicol 43:75-80

Precht H (1958) Concepts of the temperature adaptation of unchanging reaction systems of cold-blooded animals. In: Prosser CL (ed) Physiological adaptation. American Physiological Society, Washington DC, pp 50-78

Sandahl JF, Baldwin DH, Jenkins JJ, Scholz NL (2005) Comparative thresholds for acetylcholinesterase inhibition and behavioral impairment in coho salmon exposed to chlorpyrifos. Environ Toxicol Chem 24:136-145

Scaps P, Borot O (2000) Acetylcholinesterase activity of the polychaete Nereis diversicolor: effects of temperature and salinity. Comp Biochem Physiol Part C: Pharmacol Toxicol Endocrinol 125:377-383

Scholz NL et al (2000) Diazinon disrupts antipredator and homing behaviors in Chinook salmon (Oncorhynchus tshawytscha). Can J Fish Aquat Sci 57:1911-1918

Schwarzenbach RP et al (2006) The challenge of micropollutants in aquatic systems. Science 313:1072-1077

Scott GR, Sloman KA (2004) The effects of environmental pollutants on complex fish behaviour: integrating behavioural and physiological indicators of toxicity. Aquat Toxicol 68:369-392

SFEI (2008) The pulse of the estuary: monitoring and managing water quality in the San Francisco Estuary. San Francisco Estuary Institute 2008 annual report

Sommer T et al (2007) The collapse of pelagic fishes in the upper San Francisco Estuary. Fisheries 32:270-277

Stevens DE, Kohlhorst DW, Miller LW, Kelley DW (1985) The decline of striped bass in the Sacramento-San Joaquin Estuary, California. Trans Am Fish Soc 114:12-30

Strange CJ (2008) Troubling waters. Bioscience 58:1008-1013

Thompson B, Hoenicke R, Davis JA, Gunther A (2000) An overview of contaminant-related issues identified by monitoring in San Francisco Bay. Environ Monit Assess 64:409-419

van der Oost R, Beyer J, Vermeulen NPE (2003) Fish bioaccumulation and biomarkers in environmental risk assessment: a review. Environ Toxicol Pharmacol 13:57-149

Wang J, Grisle S, Schlenk D (2001) Effects of salinity on aldicarb toxicity in juvenile rainbow trout (Oncorhynchus mykiss) and striped bass (Morone saxatilis $\times$ chrysops). Toxicol Sci 64:200-207

Wheelock CE et al (2005) Individual variability in esterase activity and CYP1A levels in Chinook salmon (Oncorhynchus tshawytscha) exposed to esfenvalerate and chlorpyrifos. Aquat Toxicol 74:172-192 